\title{
WHO OWNS IT? THREE ARGUMENTS FOR LAND CLAIMS \\ IN LATIN AMERICA*
}

\author{
¿A quién le pertenece? Tres argumentos para el reclamo de tierras \\ en América Latina
}

\section{CHRISTIAN BARRY}

School of Philosophy, Australian National University

\section{GERHARD ØVERLAND}

Department of Philosophy, Classics, History of Art and Ideas, University of Oslo

\begin{abstract}
Indigenous and non-indigenous communities in Latin America make land claims and support them with a variety of arguments. Some, such as Zapatistas and the Mapuche, have appealed to the "ancestral" or "historical" connections between specific communities and the land. Other groups, such as MST in Brazil, have appealed to the extremely unequal distribution of the land and the effects of this on the poor; the land in this case is seen mainly as a means for securing a decent standard of living for members of disadvantaged groups. Although there is a large literature on the history as well as the social and political dimensions of land contestations and conflicts in Latin America, the question of whether the land claims put forward by disadvantaged groups can be morally justified has not been adequately examined. In this essay, we investigate the scope and limits of appeals to what we shall call assistance-based, contribution-based, and benefitting-based moral reasons with respect to land claims made by these disadvantaged groups.
\end{abstract}

Keywords: land claims, rights to land, landless movement, benefiting from injustice, rectification, duties to assist

\begin{abstract}
RESUMEN
Distintas comunidades en América Latina (indígenas y no indígenas) han realizado reclamos de tierras sobre la base de una variedad de argumentos. Algunas de esas comunidades y grupos, tal como los zapatistas y el pueblo Mapuche, han efectuado estos reclamos apelando a conexiones "ancestrales" o "históricas" entre comunidades especificas y un territorio particular. Otros grupos, tal como el movimiento sin tierra (MST) en Brasil, sustentan sus reclamos en rechazo a una desigual extrema en la distribución de la tierra y los efectos que este fenómeno tiene sobre los más pobres. En este caso, la tierra se concibe como un medio esencial para asegurar un nivel de vida digno para los miembros de esos grupos desaventajados. Aunque existe una extensa literatura sobre la historia, las dimensiones politicas y sociales de los reclamos territoriales en América Latina, la pregunta sobre en qué medida esos reclamos puede ser moralmente justificados no ha sido adecuadamente examinada. En este ensayo
\end{abstract}

Thanks to Alejandra Mancilla, Avery Kolers, Anne Gelling, Luiz Pericás, and the Editors and anonymous reviewers of this journal for comments on an earlier version of this essay. We also gratefully acknowledge the financial support of the Australian Research Council and the Research Council of Norway. 
evaluamos el alcance y límites de los reclamos de tierras realizados por estos grupos desfavorecidos que se sustentan en tres tipos de razones morales: basadas en asistencia (assistance-based), en contribución (contribution-based) y en beneficios (beneffiting-based).

Palabras claves: reclamos territoriales, derechos territoriales, movimiento sin tierra, beneficiarse de la injusticia, rectificación, deber de asistencia

\section{INTRODUCTION}

In the past twenty years, dozens of social conflicts have taken place in different Latin American countries, triggered by unmet land claims. These claims are also sometimes accompanied by demands for political self-determination and territorial rights. Both indigenous and non-indigenous communities make land claims and support them with a variety of arguments. Some, such as Zapatistas and the Mapuche, have appealed to the "ancestral" or "historical" connections between specific communities and the land. Other groups, such as MST in Brazil (Movimento dos Sem Terra or Landless Workers' Movement), have appealed to the extremely unequal distribution of the land and the effects of this on the poor; the land in this case is seen mainly as a means for securing a decent standard of living for members of disadvantaged groups.

Although there is a large literature on the history as well as the social and political dimensions of land contestations and conflicts in Latin America (Yashar 1998; Moyo and Yeros 2005), the question of whether the land claims put forward by disadvantaged groups can be morally justified has not been adequately examined. It is a difficult undertaking, requiring both a nuanced understanding of the history of these conflicts and the political policies open to these societies, and an account of the principles relevant to determining if the claims are sound, given these facts. Other essays in this special issue help to provide a richer understanding of the historical and political contexts of these conflicts. This essay explores the nature of some of the arguments that the communities involved can make.

In particular, we investigate the scope and limits of appeals to what we shall call assistance-based, contribution-based, and benefitting-based moral reasons with respect to land claims. Note that we do not evaluate to what extent these groups have a warranted legal claim on the land according to the legal systems of the countries in question. ${ }^{1}$ We are simply considering the strength of their claims according to some moral principles that seem potentially relevant in this context. If there are moral claims to land then these can provide good reasons to establish legal claims to it. But moral claims do not entail legal claims, nor vice versa. 
We have no illusions, of course, that resolving land disputes in Latin America is an easy task, even at a fairly abstract level. Still, clarifying the scope and limits of arguments that these groups might invoke is certainly an important step in addressing the complex practical issues involved in assessing their particular claims.

\section{PRELIMINARIES}

In any discussion of land claims, it is important to consider the different communities and their relation to the land at issue. We must ask, "What is at stake for the parties involved with respect to this particular claim?" In one sense, the answer to this question will be simple and uniform: rights to land are at stake. And since the land will often be used for farming, possessing the means to avoid poverty and improve living standards will also be at stake.

But much else may be at stake. It may also be that a certain way of life is at stake, and that it has particular value to the claimants - that is, land may be a means to protect a certain way of life, one that will typically involve not just the life of particular individuals but also the communities to which they belong. The people making the claims may have what Anna Stilz (2013) has called "located life plans" connected to the areas that they are claiming. So the significance of a claim will sometimes depend on the importance of the way of life of the community for its members, and in particular how the continuity of the community protects their interests in maintaining relationships and advancing life projects in the place where those projects and relationships have previously been developed and pursued (Kolers 2012).

Talk of "ways of life" might seem vague and imprecise, but its meaning is clear enough in particular cases. If a community's practices, rituals, and aesthetic sensibilities are strongly connected to the use of a particular territory, it seems appropriate to say that their way of life is connected to this territory (Armstrong 2014). And if a person's identity and ambitions are closely connected to their participation in the life of a community, then the continuation and well-being of their community will be important to their personal well-being.

It is also important to recognize the different kinds of claims that may be in question. The phrase "land claims" is ambiguous: it may refer to claims to have access to land and to move through it, to make productive use of land, or to gain fully fledged property rights over land (including the right to pass on or exchange the land with others) (Waldron 1988). When the claims are being made by an organized collective, they may be more appropriately conceived as 
territorial claims, which would confer a range of privileges and powers on the group with respect to the land (Kolers 2009).

In conflicts over land, there are typically several groups with something at stake. First, both indigenous and non-indigenous people are claiming title to land. The land may be currently owned by the state or by private landowners. These groups may be seen as the main ones with a stake in the issue, but other parties may be relevant to the conflict and its resolution. The rest of society may have a stake in whether and how some proposed allocation of land claims be carried out-obviously in relation to the extent to which they should be asked to bear the cost as a result. If the state is not in possession of the land, it may be a question of transferring land to the new owners while at least partly compensating the current owners for their losses. In such cases, the question will be who, within society, should be asked to bear the cost of such transfers. It is important to realize that honoring a land claim may risk imposing undue burdens on other groups. When it seems justified that the private landowners give up some of their property to the claimants without being compensated, much less is at stake for the wider society.

\section{ASSISTANCE-BASED RESPONSIBILITIES}

Assistance-based moral responsibilities have been frequently appealed to in philosophical arguments regarding the responsibilities of affluent people to address global poverty, at least since Peter Singer's (1972) seminal article, "Famine, Affluence, and Morality." The idea behind assistance-based responsibilities is that there is a relevant difference between the prospective recipient and the prospective provider of assistance: typically the former is at risk of lacking the means to satisfy basic needs, while the latter is able to provide such means without incurring a comparable risk, and therefore incurs a responsibility to do so. ${ }^{2}$

There are different ways to justify assistance-based responsibilities. Singer's analogy is well known:

if I am walking past a shallow pond and see a child drowning in it, I ought to wade in and pull the child out. This will mean getting my clothes muddy, but this is insignificant, while the death of the child would presumably be a very bad thing (Singer 1972: 231).

Just as any passer-by is morally required to make the necessary sacrifice to save the child, so too the affluent are required to assist people in need throughout the

The related but distinct capacity- or ability-based reasons (Miller 2001; Caney 2010) allocate responsibilities to achieve some end in accordance with the capacity of different agents to further it. When a person has an assistance-based responsibility to help another, they must have some capacity to help them, but this does not mean that they are most capable of helping them or more capable than any others. 
world. But theorists differ greatly over just how demanding such responsibilities are.

\section{Demandingness}

How much cost are we required to bear to assist others in severe need? This is a matter of heated dispute among philosophers. Singer has formulated three versions of his principle of assistance, all of which demand a quite significant level of sacrifice by prospective assistors. He presented the first two formulations in "Famine, Affluence, and Morality," and the third-the least demanding-appears in his book The Life You Can Save (Singer 2009: 15): "if it is in your power to prevent something bad from happening, without sacrificing anything nearly as important, it is wrong not to do so." But even this principle is quite demanding, because anything nearly as important might still be quite important when what is at stake for the other person is very important. In our view, Singer's principle seems more plausible at first glance than it does on reflection, because what is not nearly as important as something else is often not very important at all, such as getting one's clothes muddy.

How demanding is Singer's principle? Much depends upon how the notion of relative importance is understood; Singer does not give explicit guidance, but leaves it up to his readers to interpret on the basis of their intuition (Singer 2009: 17). It appears to us that even Singer's least demanding version of a principle of assistance is quite demanding. For instance, are we morally required to sacrifice our hands or limbs to save the life of a child in front of us? While we do not think that this would be required, it is hard to argue that a hand is nearly as important as another person's life. The principle seems implausibly demanding.

Bear in mind that in the initial pond case, all that is at stake for the passerby is getting his clothes wet and being late for a meeting. There is no need to appeal to anything nearly as demanding as any of Singer's assistance principles to explain the judgment that the passer-by fails in his duty if he fails to rescue the child. There are various other, much less demanding principles that would explain this. The cost that the passer-by is asked to bear seems minimal indeed.

Intuitively, though, it doesn't seem too demanding to ask a person to shoulder a moderate cost to prevent something that is really very bad from happening to another person. While having an unbecoming haircut or losing a fingernail could be widely seen as a minimal cost, the sacrifice of a finger, however, seems better described as moderate. Losing a finger is not a negligible loss, but compared to what is at stake it is nevertheless relatively moderate. Yet some (and perhaps many) would think that you ought to sacrifice a finger to save a child, unless perhaps you are a pianist or rely, for some other reason, on having all of your fingers to ply your trade or do what you love most. 


\section{Land}

The crucial question in this context is, of course, how such assistance-based responsibilities would apply to land claims. Note first that assistance-based responsibilities seem to get real traction when what is at stake is something very important for the prospective recipient of the assistance, and when providing the assistance would not impose more than a moderate cost on the prospective assistor. We are assuming that the people in question have no special connections to each other (such as being friends or family members), in which case their responsibilities might be more stringent. While some people may think that assistance-based responsibilities could be triggered even when there is much less disparity in the means possessed by the prospective assistor and recipient-as when a well-off person can take on a cost to avert a very small misfortune to another slightly less well-off person-this is not a widely-shared view, and we shall not assume it.

Is lack of title to land alone sufficient to trigger assistance-based responsibilities? Surely not, if we are interpreting title to land as having rights to exclusionary use. Many affluent people in many countries are unlikely to hold land rights in this sense, yet are clearly not appropriate recipients of assistance. Of course, they do have rights to use and occupy various spaces, but that is different from the sorts of claims that groups demanding land typically put forward. Lack of title to land must therefore be a proxy, because it is needed to satisfy some other relevant need if it is to trigger assistance-based responsibilities.

The most obvious candidate here would be poverty or severe disadvantage. It is generally accepted that poverty is materially bad for those suffering it, and that it can be demeaning and even humiliating. For these reasons it is ordinarily thought to be very important that societies take measures to ensure that it is relatively easy for citizens to avoid severe poverty-nearly all discussion of assistance-based responsibilities has been oriented toward the question of how much cost individuals should take on to address severe poverty. Of course, it is a further question whether giving poor people claims to land is the appropriate manner of discharging the assistance-based responsibility to relieve their poverty: it may not be the most effective way to mitigate their need and may not be effective at all.

Even if it does seem an effective way to mitigate their need, it may well not be the least costly way of doing so. It is also not obvious that the manner in which assistance is offered should be at the discretion of the recipient; even if the recipients of assistance prefer land to money or other goods as a means of improving their living standards, it may be that responsibilities to help them escape poverty can be met without providing them with land. Indeed, when granting title to land is not the most efficient manner of ensuring that the basic needs of recipients are met and there is a limited amount of resources that those providing assistance are responsible to give, they may be required not 
to discharge their responsibilities through giving title to land, since doing so would result in fewer people having their basic needs met.

The second way in which assistance-based responsibilities could come into play is that land, or a particular piece of land, is essentially linked to other aspects of the well-being of the people in need. As noted, people might feel a very strong connection to the land because they have located life plans there; severing a connection to the land that is so tightly tied to their sense of identity may cause them great distress. Of course, this type of argument will only apply to those cases where the well-being of those claiming title to land is, as a matter of fact, closely linked to that land. ${ }^{3}$

Indigenous groups might also seek autonomy and some independence from the larger community in order to secure and be able to control their future. The extent to which their way of life differs from that of the larger community may entail a need for space to do this. It may be that possessing claims to land will be essential for them to-or make them best able to-secure this type of control, even if they are not materially poor.

It may seem harder to argue that non-indigenous people's well-being is essentially tied to land, let alone to a particular piece of land. Of course, farmers sometimes talk as if this were the case, but it is not clear that this claim should be treated differently from claims for assistance by miners, academics or artists, who may argue that their well-being is essentially tied to a particular kind of work. Even so, this doesn't mean that such considerations should play no role in determining claims to land. It may be that certain "traditional" trades, like farming, should be given extra weight as a practical matter, since practitioners may lack education and therefore be less able to adapt and participate fruitfully in other areas of economic activity, thus making it more likely that their wellbeing is indeed dependent on a way of life that is linked to the land. Providing land may also sometimes be the most effective way to solve a particular conflict, and also the most efficient way to provide "assistance" to groups of people who are capable of using the land to achieve decent standards of living.

But there are limits to employing arguments that assert assistance-based responsibilities to support land claims. While there is relatively widespread agreement that poverty can trigger assistance-based responsibilities, there seems to be less agreement that the lack of well-being that some people may experience (falling short of poverty) as a consequence of not having title to land also triggers assistance-based responsibilities. A person's material (or "objective") well-being may well diverge from that person's well-being as they themselves understand it. But as Scanlon (1975) has pointed out, when deliberating about the distribution of resources, we often give weight to considerations of material rather than subjective well-being; he gives the example of a man who would 
prefer to build a monument to his god than to eat, and argues that we should nevertheless take his claims to food more seriously than his claims to help in building his monument.

\section{Poor farmers}

The most widely applicable type of argument that poor farmers can employ appeals to assistance-based responsibilities. The farmers are in severe need, which can be met by access to productive land; moreover, providing them with such land may not be very costly. This sort of argument seems to have a great deal of traction in countries, like Brazil, with a very unequal distribution of land. In Brazil, a large proportion of farmland is unproductive and many millions live in extreme poverty (UNICEF 2017). Given that the plight of these disadvantaged groups could be alleviated by giving them land-public or private-on which no one depends, there would appear to be an assistance-based responsibility for the Brazilian government to do so.

It may therefore be no surprise that on 16 April 1996, 12,000 landless squatters built an encampment in the Fazenda Giacometi, an unused property of 80,000 hectares in Paraná, Brazil. It was the biggest illegal occupation by the MST, the largest grassroots movement in Latin America, founded in 1984 to fight for agrarian reform and land rights for poorer communities. MST in Brazil has repeatedly appealed to the extremely unequal distribution of the land and its effects on the poor (Carter 2005). Over the past 15 years 1\% of the landowners (around 40,000 latifundiários or ranchers) have been in possession of over $40 \%$ of the land (around 360 million hectares), while about 25 million peasantsmainly mestizos and the descendants of European immigrants-remained landless (Stedile 2002; Pericás 2017). The MST views its initiatives as consistent with the principles underlying the underutilized constitutional provisions for the expropriation of rural property that is not performing its social function (Brazil Constitution, Title VII, Chapter III).

Clearly, if poor farmers demand title to land because of assistance-based responsibilities, they will compete with other needy groups in society, such as those who live in the shantytowns of urban centres. It seems unlikely that assistance-based arguments should give any particular preference to farmers above poor urban dwellers (for instance, based on the idea that farmers have a particularly close connection to the land and that their well-being is therefore connected to farming). Any redistribution of land, where the larger society bears its cost, must simultaneously be weighed against improving the conditions for all poor people in the society. This is not to say that there will always be a conflict between solving land disputes and improving the conditions of the urban poor: giving impoverished farmers title to productive land may benefit poor urban dwellers simply by reducing the number of poor people migrating to the towns. 


\section{CONTRIBUTION-BASED RESPONSIBILITIES}

The second argument we want to consider is based on the idea that because either the communities who are claiming title to land or their ancestors were unjustly dispossessed, and these communities have consequently been kept in a state of poverty and deprivation due to their continued exclusion from the land, the state and those who currently occupy the land have a responsibility to rectify this situation by reforming the current legal order that sustains it. We call the responsibilities arising in such contexts contribution-based responsibilities (Barry 2005).

Contribution-based moral reasons play a very substantial role in many people's moral thinking. This is true for retrospective assessment, in that the significance of one's reasons to bring remedy to or to compensate for severe deprivations that occurred in the past is generally taken to depend in part upon whether one has contributed to these deprivations. It is also true for prospective assessment, in that the significance of our reasons to address presently occurring severe deprivations and to prevent future deprivations is generally taken to depend in part upon whether our past or present conduct is contributing or will have contributed to their occurrence.

Contribution-based responsibilities are widely acknowledged. Most people affirm that there are stringent moral requirements for us not to contribute to wrongful harm and to compensate those who have been wrongfully harmed as a consequence of us failing to meet these requirements. It is very important not to do or enable harm to innocent others, and if we do so, we must compensate those to whose harms we have contributed (Pogge 2002). Since most people view contribution-based responsibilities as quite stringent and demanding, appealing to them (at least when such appeals are plausible) may have greater motivational force than appeals to assistance-based responsibilities (LawfordSmith 2012). The violation or usurpation of rightful land claims is generally acknowledged as a clear-cut case of injustice or wrongdoing, even by those who are skeptical about other ideas of distributive justice (Nozick 1974; Boxill 2003). It is no surprise, then, that land claims are often framed by an appeal to some unjust appropriation that occurred in the past.

\section{Historical contribution}

The most straightforward argument that indigenous people employ is to appeal to historical injustices. They may argue that the land they are now claiming title to is in fact their land (Thompson 2001; Torpey 2003). In such cases, the alleged contribution refers to the wrongful dispossession of particular lands that previously belonged to these groups. This argument is typically invoked when indigenous peoples demand that "ancestral" or "historical" territories be returned to them, as in the case of the Mapuche in the Araucanía Region 
in Chile (Carruthers and Rodriguez 2009), the Awajún and Wampis in the Peruvian Amazon (Acuña 2015), and the indigenous peasants in Chiapas, Mexico (Harvey 1998).

The Mapuche claim that the "historical debt" owed to them by the Chilean state goes back as far as the end of the 19th century, when they were deemed to have a valid claim to only 500,000 hectares (5\% of what they had traditionally inhabited and then claimed). They also demand restoration of the 300,000 hectares taken from them during Augusto Pinochet's dictatorship (1973-90) (Aylwin 2000). In the case of the Zapatistas, one of their principal grievances concerns how the privatizations carried out by recent Mexican governments have marginalized and impoverished indigenous communities, sometimes forcing them out of the areas that they had traditionally inhabited (Collier and Quaratiello 2005).

But there are challenges that must be faced when invoking such arguments. For arguments asserting contribution-based responsibilities to get traction, it must be possible to identify those people who have contributed to a wrongful harm (the contributors) and those to whose hardships their wrongdoing has contributed (the victims). Let's call this the identification challenge. If we can identify the contributors but not the victims, or if we discover that the victims are all deceased, the contributors may be blamed, punished, or forced to disgorge their ill-gotten gains, but it is not clear that they owe any compensation to anyone who now exists. If we can identify the victims but not the perpetrators, it may be clear that some people deserve compensation but prove difficult to identify particular people who have contribution-based responsibilities to provide it. ${ }^{4}$

The identification challenge can be significant in land claims. For instance, in a great many cases the individuals who were directly deprived of their land are no longer alive, and the connections that their descendants have to the land may be tenuous. The perpetrators who unjustly usurped the land also no longer exist. This can make it difficult or even impossible to determine, on contribution-based grounds alone, who should be compensated, how they should be compensated, and who should bear the cost of compensation.

Sometimes the state or some other collective agent is held to play the role of the past contributor. If it was the state that perpetrated the injustice and expelled indigenous people from their land, the state may have some responsibility to compensate descendants of the victims. States are typically taken to persist through time (and to sustain duties through time), even if particular governments and the individuals comprising them-and the ordinary citizens who sustain them-change (and indeed even if they undergo regime change). Even if it were not the state that expelled people from their land, the state may nevertheless have a responsibility to offer compensation to the victims,

There may be some tendency, of course, to give more consideration to the claims of people who are in need as a result of wrongdoing than to those who are in need for other reasons (like a natural disaster), but it is unclear that this is justifiable. 
because it enabled the perpetrators to carry out their misdeeds, or should have prevented or regulated differently what took place.

Another aspect of the identification challenge is the so-called "non-identity problem." Altogether different people would now be alive had history taken a different trajectory, including one in which the injustices in question had not taken place (Parfit 1987; Broome 1992). In what sense, then, can we identify people alive now as the victims of such wrongful harm, at least insofar as their lives are worth living? ${ }^{5}$

Furthermore, such arguments must determine what is owed to the victim of the past wrongdoing or their descendants. One common strategy is to appeal to counterfactuals. Individual claims to rectification are based on what would have happened had the initial injustice not occurred; for example, it is asserted that if the injustice had not taken place, the descendants of the victims would now be better off than they are, while the descendants of those who perpetrated the injustice would be worse off than they are. Jeremy Waldron (1988) has pointed out that such claims may amount to no more than mere conjecture. Would the traditional owners of the land have held on to it and increased its value? Would they instead have sold or squandered it? We will not always be able to answer these questions with much confidence.

Another option is to say that the descendants of the victims are entitled to what they would have had if their forebears had retained their land and behaved prudently, whether or not this seems likely (Cohen 2009). A difficulty with this claim, as Waldron (1992) argues, is that often we don't define entitlements by what it would have been rational to do, but rather by what was in fact done, and it's a safe assumption that in many cases what would have been done would have been irrational. If a person makes a bet that they can be expected to lose, and they do in fact lose, we treat that bet as defining their entitlements-they lose their entitlement to the money that they placed on the bet. If the gambler then says, "I am entitled to keep that money because if I had been acting rationally I never would have taken the bet," we don't think this carries much weight. So what allows us to uphold entitlements based on hypothetical rational choices in the one example but not the other?

In any case, we also need to consider how plausible it is to apply such counterfactuals in order to assess a person's contribution-based responsibilities. Suppose Bill has decided to steal his neighbor's car and camping wagon the next day and to set off on a long journey. But just before he does it, Jane steals the car, destroys it in a crash, and ends up safe at the hospital. As it now stands, Bill's neighbor is better off than if Jane had not stolen the car, but that doesn't mean that she is not required to compensate him for the destruction of his car. 
The problem with historical contribution-based arguments therefore seems to be something else, which is related to the passing of time and a blurred understanding of the specific causal links. When Jane is asked to compensate Bill's neighbor, we can identify clearly the relevant causal links between her and the victim, and what she is required to offer by way of compensation; by contrast, we lack understanding of the causal links in many historical cases. However, if a counterfactual understanding of harm seems wrong for simple cases, there is little reason to think that it is correct in more complex instances. The relevant uncertainties in relation to claims in complex historical cases, then, would be about knowing the specific causal processes and not about the truth of various counterfactuals.

A further challenge to arguments that use contribution-based responsibilities to support land claims is that circumstances can change in ways that make complete restitution of land unjustified. Given population growth and scarce resources, justice may require that the original owners of land share it with others, including the descendants of those who unjustly appropriated the land from their ancestors (Waldron 1988). Furthermore, the land of which people were unjustly dispossessed may now be inhabited by people who were not involved in this dispossession and who now have located life plans tied to these territories (Stilz 2013). As for indigenous groups such as Zapatistas and the Mapuche, their "ancestral" or "historical" connections between specific communities and the land may have been severed or weakened substantially, not least during the military dictatorships of the 1970s and 1980s (Carruthers and Rodriguez 2009). In some cases, the indigenous groups or their representatives may in fact have agreed to "sell" their land a long time ago, albeit under varying degrees of coercion.

This does not, of course, mean that such considerations entirely disregard land claims made by unjustly deprived people and communities, particularly with respect to more recent injustices that have deprived these groups of resources that were rightly theirs, or where the land to which communities are making claims has larger cultural significance for them (Sher 1981, 2005). Rather, it makes determinations of the appropriate form and degree of restitution complex and, consequently, a matter of reasonable controversy. It may also be worth observing that the communities making historical claims in Latin America do not typically demand that all lands traditionally held be returned to them, but rather that they receive some share of these lands. Waldron claims that when, due to changing circumstances, the land must now be shared by the original owners, this is incompatible with the claim that these owners should be compensated for having to share the land; on Waldron's account, the changing circumstances target entitlements to the land, not the claim for compensation. So it seems that his argument needs an extra step: why do changing circumstances entail that 
current owners must share the land and, at the same time, undermine their claim for compensation for having to do so? ${ }^{6}$

There is a different type of historical contribution-based argument that bypasses these difficulties. This sort of argument (a version of which has been made forcefully in the context of reparations to descendants of African-American slaves by Bernard Boxill) focuses on the injustice done not to the original owners but to their descendants. The idea is that insofar as reparation for injustice is withheld from its initial victims, this may impose a fresh injustice on their descendants. When a group usurps land from Luiz, it harms him; insofar as it continues to sustain the harm he suffers by preventing him from being compensated or regaining title to the land, it continues to contribute to his deprivation, and it may also thereby contribute to the deprivations of his children. When Luiz dies, he will no longer be unjustly harmed-nor will his children "inherit" these claims, but they will retain their claims to reparation for the unjust harms they have suffered.

Those who have made this sort of argument have typically conceived of the harms suffered in terms of costs that would not have been borne had reparation been made (Boxill 2003; Sher 2005). We think this idea is a mistake, for the same reasons that it is a mistake to ground other historical contribution-based arguments in counterfactuals. Even if the children would have been worse off if their parents had received reparation (imagine that this would have had perverse incentives), this would not seem to defeat their claim to reparation: what actually occurred was a process through which they were unjustly harmed, and the fact that some other process might have harmed them more is irrelevant from the moral point of view-so long as the prevention of this greater harm was in no way a motivation of the parties who caused the harm.

\section{Institutional contribution}

Due to the generational problem of historical injustice, it may be wise to explore another type of contribution-based argument. Indigenous groups may allege that currently affluent people and state officials have contributed to injustices that they have suffered by upholding and enforcing an unjust institutional orderlaws and other social rules governing what kinds of things can be owned (and by whom); how they can be acquired, transferred, relinquished, and forfeited; how markets and the production systems are structured; the manner in which decisions concerning education and health are made; and so on-that has kept these communities in a severely disadvantaged position.

Suppose my friend is kicked out of his home and can't find any new accommodation (the circumstances of the rental market mean that there is nothing available for him). In light of his vulnerability, perhaps I ought to share my spare room with him, but that doesn't mean I can't demand he contribute to sharing the costs of maintaining it. 
In some instances, it is claimed, governments have inherited unjust arrangements from illegitimate predecessor regimes but have failed to reform them. One of the main complaints of the Mapuche, for example, is that since 1990 successive democratic governments have ignored their demands to be compensated for injustices perpetrated by the Pinochet dictatorship (Lavanchy 1999). In other cases, groups claim that governments have enacted policies that have further contributed to their deprivations, or that governments have failed to enforce laws and agreements that would have protected them.

Such arguments bring to mind a notion of contribution that has been emphasized in recent years by the philosopher Thomas Pogge, who argues that when affluent people collaborate, avoidably, in imposing an institutional order in which people's human rights foreseeably go unfulfilled (a relatively minimal conception of justice), they are contributors to injustice and have stringent duties to reform these institutions and to compensate those who suffer as a result of them (Pogge 2002). This notion of contribution is based on a prior conception of justice. Those who do not make efforts to reform institutions that are unjust, withdraw from participation in the social domains they govern, or compensate those who are treated unjustly by them, have contribution-based responsibilities to address the needs of those who suffer under them.

This institutional argument has broader scope than those based on past contribution. It may therefore also apply to poor farmers, such as the MST in Brazil, who have in many cases not been dispossessed of land. If it could be argued that poor farmers are poor because some agents have made them so, or at least helped to perpetuate their poverty, then it could be argued on the basis of contribution-based reasons that those who have contributed to this ought to compensate these poor farmers. If the MST and poor farmers in general can appeal to contribution-based moral reasons, it seems that they would need to appeal to an institutional type of contribution. They may argue that affluent people and state officials have contributed to injustices that their communities have suffered by upholding and enforcing an unjust order that has kept them in a severely disadvantaged position.

However, while this institutional argument has broader scope than those based on past contribution, it invokes a substantive conception of justice, and is therefore likely to be more controversial than cases of straightforward theft and dispossession-just how controversial depends on the substantive conception that is supposed.

\section{BENEFITTING-BASED RESPONSIBILITIES}

An additional moral reason that may be appealed to by groups making land claims is that various social actors within their societies have benefitted or are benefitting from wrongful harm that they have suffered or are suffering. This argument-less common than arguments of the first two sorts-appeals to the 
idea that, even if the state and current occupiers of the land did not cause or could not have prevented the unjust exclusion of people from the land, they have a duty to compensate the wronged people because they have benefitted from these injustices. Even if specific affluent individuals in Latin America have not contributed to an injustice, and even if they were not in a particularly salient position to have prevented the injustice from occurring or to have assisted its victims when it occurred, they may still-if they benefit or have benefitted from the injustice-have some additional responsibility to bear cost now to help those who suffered the injustice.

In discussing contribution-based responsibilities, we noted that the past contribution of some agents to unjustified harm does not necessarily generate duties on the part of the present generation, since this generation may not have contributed to such harm. This makes it important to understand the extent to which contemporary beneficiaries of such harm can have responsibilities toward people who suffer as a result of it. There is an important difference between contribution-based arguments and beneficiary-based arguments: only in the former do we need to identify the contributors to the injustice or harm in question, even though the beneficiaries of injustice may also be contributors.

There are various ways in which this principle of benefitting from injustice might be understood. For our purposes, we will understand the principle of benefitting from injustice as stating that agents have a particularly weak claim on the benefits that have been derived from an injustice and may for that reason be required to relinquish some of these benefits to those who suffer as a consequence of the injustice.

It seems hard to deny that many people living in settler societies have captured benefits arising from wrongs done to the indigenous populations of the lands in which their ancestors settled (Miller 2004, 2010). In the case of Latin America, the Spanish, Portuguese, and (later) other European immigrants populated these territories to the exclusion of the indigenous peoples. It seems quite plausible that beneficiary-based responsibilities may play an important role in the current debates about land claims in such formerly colonized societies. The fact that many of the descendants of these European immigrants - often members of the local elite-enjoy a high standard of living seems to confirm that they benefitted and will continue to benefit from those past injustices (Ypi et al. 2009; UNDP 2010). ${ }^{7}$

The idea is that when the current owners acquired their land cheaply due to a past injustice, the former occupiers may have a stronger claim on this land, or part of it, than if they simply had to appeal to the assistance-based responsibilities

It is worth noting that an important difficulty for considering the application of benefitting-based responsibilities is the large number of mestizo people in Latin America. Here it may be quite difficult to differentiate benefits and burdens when a great many people stand in a complex relationship to earlier injustices. We are grateful to an anonymous referee for emphasizing this point to us. 
of these owners and others. Insofar as the current landholders have benefitted from an injustice and their claims to it correspondingly weakened, it may be easier to redistribute some of this land to people who are the descendants of those who used to occupy the land.

Such arguments could plausibly be directed against present landholders of areas that previously were populated by the indigenous peoples or that have been currently acquired under laws or agreements of dubious origins-for example, decreed by illegitimate rulers or signed without the consent of the majority.

But just as one can benefit from a past injustice and therefore may be held responsible for compensating the victims of the injustice, one may also benefit from present injustices that are engendered by the institutional order that prevails in a society. This means that people who are affluent under the current scheme may have a particularly weak claim on their assets: these assets may be "tainted" by having been obtained (although innocently) by their owners through the imposition of an unjust scheme. If the argument based on such benefits is correct, this would imply that the owners may have to relinquish some of these benefits to the victims of the past and ongoing injustice.

In what way can groups like MST appeal to benefitting-based moral reasons to support their claim on (farm) land? For one thing, they can complain that the present holders of vast landed estates are the beneficiaries of past injustices. These landholders benefitted from the creation of latifundiários that unjustly excluded people from land that was subsequently passed to them; they received their land-cheaply, too-because other people were expelled from it. Second, MST can complain about a present unjust institutional scheme that continues to benefit rich landholders. In this case, MST has a better claim to some of the assets in question since its members are also victims of the current institutional injustice.

\section{Scope}

Arguments that assert beneficiary-based responsibilities share some of the features of those relating to contribution-based responsibilities, and consequently are vulnerable to similar challenges. For example, if such arguments are to be cogent, it must be possible to establish some relation between the beneficiaries of particular injustices and their victims; this depends on establishing causal relations between these sets of people and the wrongful harm that was originally inflicted. But although the relations are causal, they are causal in a very different way from those based on contribution-the idea is not that the beneficiary caused the injustice but that whatever caused the injustice also caused the benefits received by some person(s).

If, for whatever reason, your benefits are derived from an injustice, then your claim to these benefits is correspondingly weakened, and you may consequently 
be required to give up some or all of these benefits in order to help the victims of the injustice. Even if you have received similar (or greater) benefits from another source in the absence of the injustice, your present benefits are still "tainted" by the injustice from which they arise. Nor does this duty depend on counterfactual judgments about what would have happened to the victim had the injustice not occurred: if you receive benefits arising from Jane's theft of the car, it does not matter that Bill would have stolen the car had she not done so. That these benefits are tainted by injustice weakens your claim to them.

There is, of course, a different view of benefitting-based responsibilities that holds that talk of benefitting from an injustice implies that someone is made better off by its occurrence relative to a counterfactual baseline: some state of the world to which another state of the world can be compared. This view holds that we can only begin to understand what it means to benefit from injustice by examining the different baselines-historical or counterfactualthat are implicitly or explicitly adopted when people claim that some agent is a beneficiary of injustice.

We think that this way of understanding benefitting-based responsibilities is problematic, just as it is problematic to think of contributing to harm in such terms. Recall again the case where Bill has decided to steal his neighbor's car and camping wagon the next day and set off on a long journey, but Jane preempts him by stealing the car and crashing it. As it now stands, Bill's neighbor is better off than if Jane had not stolen the car, but that doesn't mean that she is not required to compensate him for the destroyed car. Benefitting from injustice can be understood in a similar way. When it is a fact that certain material goods causally derive from an injustice, then those who are in possession of them have some additional moral reasons to relinquish them. This means ultimately that the unjust event may not have been a benefit to them, all things considered, since they could have fared even better if the unjust event had not happened. This is important for the question that concerns us-it implies that we do not need to consider how well off landholders would have been today in the absence of the past injustice. As long as there is a clear causal link between that injustice and the current material belongings of the landholders, then we can say that their claims to retain the land are weakened.

As a general matter, it will often be unclear how and to what extent particular affluent people have benefitted from past injustices-for example, what is the causal link between the current wealth of white Americans and the slavery that their ancestors carried out? But land may be special in this regard: in such cases, we may indeed have a fairly clear understanding of the causal link. Some groups have wrongfully lost their "right" to use particular plots of land, while others have received legally enforceable claims to this land.

It is not clear just how broad the scope of beneficiary-based responsibilities is. Some benefits seem entirely incidental to the wrongs on which they causally depend, and many benefits that causally result from injustice do not come at 
the expense of its victims-for example, the benefits received by the doctor in a war-torn region, far from coming at the expense of those who are being wronged by the conflict, arise from activities that are an important means of helping them. Cases of benefitting from injustice that result in weakened claims to retain benefits, on the other hand, typically involve the transfer of value from the victims to the beneficiaries. The cases that interest us in this essay-unjust appropriations of land-are those where the benefits received come at the expense of the victims of the wrong, involve the transfer of material value from victims to beneficiaries, and are not incidental to the wrongdoings that caused them.

Another question in determining the validity of land claims is the extent to which rich farmers acquired their land in good faith. Did they have reason to believe that, when they were granted legal title to the land, it was at the cost of some other people who used to occupy it? If so, their claim on the land today may be further weakened; if not, then it is easier for them to defend their rights to retain at least some land. It is not clear that all those who currently possess large areas of land in Latin America can be characterized as good-faith purchasers-anyone who is aware of Brazil's history, for instance, would have reason to question whether such lands are legitimately held.

\section{Stolen goods}

When the benefits are stolen goods-or goods that are mistakenly given to some who are not entitled to them, to the detriment of those who are entitled to them (as in the case of mistaken payments or misdelivered goods) - there is a strong presumption that the beneficiaries should return the goods to their proper owners. Indeed, duties of this type are incorporated in many modern legal codes: those who have mistakenly received goods or services owed to others, for example, must forfeit them or provide compensation to those who have been unjustly deprived of them (Pavey \& Matthews Pty Ltd v Paul 1987; Birks 2005).

It may be argued in some situations where indigenous people are claiming title to land that what is at stake are stolen goods that have been passed on to others. Those parcels of land that can be shown to have been stolen may thus arguably belong to the victims' descendants rather than to the current owners. But these arguments cannot often be straightforwardly applied to land claims when the parcels of land in question were stolen generations ago. If all land should be returned to its "original" owners, nearly all of it would have to change hands. Such redistribution would certainly create many practical quandaries, but there are principled concerns too. And, of course, property-based arguments depend on a theory of just initial acquisition; it is unclear how confident we can be that land has been acquired at any point in time in accordance with such principles (so long as their content does not reduce to might makes right.) 
There may be reasons why some of the goods should not be returned to their original owners. These sorts of issues arise particularly in lawyers' talk of "good-faith purchasers" of tangible goods. For example, imagine you bought a stolen car in all good faith; the asking price was not ridiculously low and you had no reason to suppose that the title certificate was forged. The treatment of good-faith purchasers in the law is mixed, but at least sometimes the law says that we should leave the good-faith purchaser in possession of the goods. Presumably, the thought that lies behind that policy, in places where it is in force, is simply that: "After all, the purchaser in good faith paid a fair price for the car; he put the right amount of his own money into it; he deserves to have the car in consequence." We thus hesitate to require good-faith purchasers to return the goods to the original owner where they have by now incorporated them into their own plans and projects that would be disrupted, imposing costs on them that may well exceed the benefits they derived from the goods (Goodin and Barry 2014). Were we confident that the benefits received instead exceeded the costs to them of returning the goods, we would of course be much less hesitant.

Similar considerations apply to the law of "unjust enrichment." Someone who receives a mistaken payment is unjustly enriched and is held strictly liable to return the monies transferred once they become aware of the mistake. But those who are unaware that they have been unjustly enriched and innocently rely upon the validity of the enrichment in ways that would make them very badly off were they now to return the payment can employ the defence of "change of position" in common law to reduce or altogether eliminate their liability (Birks 2005).

There are still further complicating factors. A second reason for supposing that the innocent beneficiary need not disgorge all—or, perhaps in the limiting case, any-of the benefits he received through the wrongdoing is that they are now inextricably intermingled with other benefits that are rightfully his, and the former cannot now be returned without unreasonable levels of damage to the latter (Goodin and Barry 2014). The innocent beneficiary's current holdings will typically be predicated partly upon his own contributions, and those in turn may have been predicated upon the wrongful benefit or may have interacted with it. We ordinarily think that people deserve to keep that portion of what they possess that is due to their own contributions, but if these are inextricably intertwined with wrongful benefits, the two principles are in clear tension: people cannot keep what is rightfully theirs without keeping what they have received as a consequence of injustice, and they cannot give back what they have wrongfully received without also relinquishing something that is rightfully theirs. Which principle should prevail over the other in such cases is an open question, and one that will presumably-at least sometimes-be decided in favor of keeping it all rather than relinquishing it all. In this case, it seems sensible to allow the possessor to keep the benefits that are intermingled in their own contributions, but also to require that they pay some appropriate value in compensation that does not amount to giving back the very object that they wrongfully received. 
Just how these considerations apply to the issue of land claims is a difficult question and will likely vary greatly from case to case. Of course, large areas of land may be divided, hence there might be a way to resolve such conflicts in a reasonably fair manner by allowing current landholders to keep some of their land while redistributing some to the descendants of previous occupiers.

\section{CONCLUDING REMARKS}

Arguments that assert assistance-based responsibilities are available to both indigenous and non-indigenous groups whenever they can point to some severe need on their part, and the capacity of others to remedy these needs at moderate costs. But there are two potential weaknesses with this type of argument in relation to land claims: it generally seems to be rather undemanding and therefore may lack motivational force, and it gives no particular significance to the issue of land claims.

Arguments that assert contribution-based responsibilities may initially be judged to be quite demanding and might therefore be thought to have more motivational force. Such arguments also single out the specific importance of land claims, since past injustices often consisted of the expulsion of the original occupiers (and users of land areas) from the land. The main problem with this type of argument is that we need to identify the contributors in order to hold them responsible, and this is not always an easy task. The fact that those who committed, colluded, and conspired in a historical injustice are often dead raises difficulties. But it may nevertheless be possible to hold the state to some extent accountable for such injustices. However, the state may nevertheless not currently be in possession of the land in question and may not therefore be in a position to compensate the past victims or their descendants. Although the state may have responsibilities to help protect victims of injustices performed by the state, it is not obvious that it can legitimately redistribute large areas of land.

Arguments that assert beneficiary-based responsibilities do not depend on identifying the perpetrators of the injustice in order to hold them responsible for the wrong and to compensate the victims. Instead, these arguments depend on identifying the beneficiaries of injustice and indicating why this should reduce their claim to holding on to these benefits. This may be possible with regard to land claims in Latin America where a very few families are in possession of very large areas; it may accordingly be argued that these families have a weak claim on this land, and for that reason it is somewhat easier to justify redistributing some of it.

The three types of moral arguments that we have identified may be used in combination to support land claims for various groups. For example, it may be argued that the state has contribution-based responsibilities to try to mitigate the wrongs that it has done or enabled (and continues to do and enable). Affluent people may be required to shoulder at least moderate costs during this process, 
and this may be due to their assistance-based responsibilities to the victims of wrongdoing, along with the fact that they have benefitted from injustices inflicted or sustained by the state. They may also be responsible for contributing to the maintenance of unjust features of their contemporary institutions.

As for the affluent landholders, they may have a particularly weak claim on the land that they possess as a result of the fact that they have benefitted from past and current injustices. This does not imply that they must immediately leave their land and hand it over to poor farmers and indigenous groups, but it does mean that it may be somewhat easier to justify a forced redistribution of some of the land areas they currently possess - this can therefore make it permissible for the state to enforce some redistribution of land that is currently held by affluent farmers who have benefitted from past injustices. In this process, both the state and the affluent in general may be asked to bear some cost so that the affluent landholders are not the only ones who bear it; for instance, landholders who are forced to give up some land may be compensated at least partly for their losses.

\section{REFERENCES}

Acuña, Roger Merino. 2015. "The Politics of Extractive Governance: Indigenous Peoples and Socio-Environmental Conflicts." The Extractive Industries and Society 2 (1): 85-92.

Armstrong, Chris. 2014. "Justice and Attachment to Natural Resources." Journal of Political Philosophy 22 (1): 48-65

Aylwin, José. 2000. "Los conflictos en el territorio mapuche: antecedentes y perspectivas." Revista Perspectivas 3 (2): 277-300

Barry, Christian. 2005. "Applying the Contribution Principle." Metaphilosophy 35 (1/2): 210227

Barry, Christian and Øverland, G. 2016. Responding to Global Poverty: Harm, Responsibility and Agency. Cambridge, UK: Cambridge University Press.

Barry, Christian and Øverland, G. 2014. "Implications of Failing to Assist." Social Theory and Practice 40 (4): 570-590

Birks, Peter. 2005. Unjust Enrichment and the Law of Restitution. Oxford: Clarendon Press.

Boxill, Bernard. 2003. "A Lockean Argument for Black Reparations." Journal of Ethics 7 (1): 63-91

Brazil Constitution. Title VII, The Economic and Financial Order, Chapter III Agricultural and Land Policy and Agrarian Reform, Articles 184-191. Retrieved from: http://www.v-brazil.com/government/laws/titleVII.html.

Brazilian Institute of Geography and Statistics. 1996. Agricultural Census. Retrieved on February 2, 2015, from http://www.fao.org/fileadmin/templates/ess/documents/world_ census_of_agriculture/main_results_by_country/brazil_2000.pdf

Broome, John. 1992. Counting the Cost of Global Warming. Cambridge, UK: The White Horse Press.

Caney, Simon. 2010. "Climate Change and the Duties of the Advantaged." Critical Review of International Social and Political Philosophy 13 (1): 203-228.

Carruthers, David and Patricia Rodriguez. 2009. "Mapuche Protest, Environmental Conflict and Social Movement Linkage in Chile." Third World Quarterly 30 (4): 743-760.

Carter, Miguel. 2005. “The Landless Rural Workers' Movement (MST) and Democracy in Brazil." Working Paper number CBS-60-05, Centre for Brazilian Studies. Osford: University of Oxford. 
Cohen, Andrew. I. 2009. "Compensation for Historic Injustices: Completing the Boxill and Sher Argument." Philosophy and Public Affairs 37 (1): 81-102.

Collier, George and Elizabeth Quaratiello. 2005. Basta! Land and the Zapatista Rebellion in Chiapas (3rd edn). Oakland, CA: Food First Books.

Goodin, Robert. and Christian Barry. 2014. "Benefiting from the Wrongdoing of Others." Journal of Applied Philosophy 31 (4): 363-376.

Harvey, Neil. 1998. The Chiapas Rebellion: The Struggle for Land and Democracy. Durham and London: Duke University Press.

Kolers, Avery. 2012. “Justice, Territory and Natural Resources.” Political Studies 60 (2): 269-286

Kolers, Avery. 2009. Land, Conflict, and Justice: A Political Theory of Territory. Cambridge, UK: Cambridge University Press.

Lavanchy, Javier. 1999. Perspectivas para la comprensión del conflicto mapuche. Santiago: Centro de Estudios Miguel Enriquez.

Lawford-Smith, Holly. 2012. "The Motivation Question: Arguments from Justice, and from Humanity." British Journal of Political Science 42 (3): 661-678.

Miller, David. 2001. "Distributing Responsibilities." Journal of Political Philosophy 9: 453-471

Miller, David. 2004. "Holding Nations Responsible." Ethics 114 (2): 240-268.

Miller, Richard. 2010. Globalizing Justice: The Ethics of Poverty and Power. Oxford: Oxford University Press.

Moyo, Sam and Paris Yeros (eds.) 2005. Reclaiming the Land: The Resurgence of Rural Movements in Africa, Asia and Latin America. London: Zed Books.

Nozick, Robert. 1974. Anarchy, State and Utopia. New York: Basic Books.

Parfit, Derek. 1987. Reasons and Persons. Oxford: Clarendon Press.

Pavey \& Matthews Pty Ltd v Paul (1987) (HPH 362).

Pericás, Luiz. 2017. “Tempos Difíceis: O MST, o Governo Dilma Rousseff e a luta no campo Brasileiro" Unpublished manuscript.

Pogge, Tomas. 2002. "Human Rights and Human Responsibilities." In Global Justice and Transnational Politics, edited by C. Cronin y P. De Greiff. Cambridge, MA: MIT Press, 151-196

Scanlon, Thomas. 1975. "Preference and Urgency." Journal of Philosophy, 72 (19): 655-669.

Sher, George. 1981. "Ancient Wrongs and Modern Rights." Philosophy and Public Affairs 10 (1): 3-17.

Sher, George. 2005. "Transgenerational Compensation." Philosophy and Public Affairs 33 (2): 181-200.

Singer, Peter. 1972. "Famine, Affluence, and Morality." Philosophy and Public Affairs, 1 (3): 229243.

Singer, Peter. 2009. The Life You Can Save: Acting Now to End World Poverty. New York: Random House.

Stedile, João Pedro. 2002. "Landless Battalions.” New Left Review 15: 77-104.

Stilz, Anna. 2013. "Occupancy Rights and the Wrong of Removal." Philosophy and Public Affairs 41 (4): 324-356.

Thompson, Janna. 2001. "Historical Injustice and Reparation: Justifying Claims of Descendants." Ethics 112 (1): 114-135.

Torpey, John. (ed.) 2003. Politics and the Past: On Repairing Historical Injustices. Lanham, Maryland: Rowman \& Littlefield Publishers.

United Nations Development Programme (UNDP). 2010. "Actuar sobre el futuro: romper la transmisión intergeneracional de la desigualdad". Informe Regional sobre Desarrollo Humano para América Latina y el Caribe. New York.

UNICEF. 2017 "Brazil: Country Statistics" Retrieved from; https://www.unicef.org/infobycountry/brazil_statistics.html

Waldron, Jeremy. 1988. The Right to Private Property. Oxford: Clarendon Press.

Waldron Jeremy. 1992. "Superseding Historic Injustice." Ethics 103 (1): 4-28.

Yashar, Deborah.J. 1998. "Contesting Citizenship: Indigenous Movements and Democracy in Latin America." Comparative Politics 31 (1): 23-42. 
Ypi, Lea. 2017. "Structural Injustice and the Place of Attachment." Journal of Practical Ethics 5 (1): $1-21$.

Ypi, Lea et al. 2009. "Associative Duties, Global Justice and the Colonies." Philosophy and Public Affairs 37 (2): 103-135.

Christian Barry is Head of the School of Philosophy at the Australian National University. He works in moral and political philosophy, with a focus on issues of international justice. His recent work includes books with Sanjay Reddy, International Trade and Labour Standards: A Proposal for Linkage (Columbia University Press, 2008), and Gerhard Øverland, Responding to Global Poverty: Harm, Responsibility, and Agency (Cambridge University Press, 2016), and articles in many leading philosophy, politics, and international relations journals. He is co-editor of the Journal of Political Philosophy. Email: christian.barry@anu.edu.au

Gerhard Øverland was Professor of Philosophy at Centre for the Study of Mind in Nature, University of Oslo. His research is in moral philosophy, and in particular issues related to global justice and ethics of war. Øverland has published leading journals such as Ethics, Journal of Moral Philosophy, Law and Philosophy, and Canadian Journal of Philosophy. He led the research projects 'Responding to Global Poverty: On what the affluent ought to do and what the poor are permitted to do' and 'Who owns it? Land claims in Latin America: their moral legitimacy and implications' at University of Oslo. 
